\title{
$\beta$-Elemene-induced autophagy protects human gastric cancer cells from undergoing apoptosis
}

\author{
Jing Liu, Ye Zhang, Jinglei Qu, Ling Xu, Kezuo Hou, Jingdong Zhang, Xiujuan Qu* and Yunpeng Liu*
}

\begin{abstract}
Background: $\beta$-Elemene, a compound found in an herb used in traditional Chinese medicine, has shown promising anti-cancer effects against a broad spectrum of tumors. The mechanism by which $\beta$-elemene kills cells remains unclear. The aim of the present study is to investigate the anti-tumor effect of $\beta$-elemene on human gastric cancer cells and the molecular mechanism involved.

Results: $\beta$-Elemene inhibited the viability of human gastric cancer MGC803 and SGC7901 cells in a dosedependent manner. The suppression of cell viability was due to the induction of apoptosis. A robust autophagy was observed in the cells treated with $\beta$-elemene; it was characterized by the increase of punctate LC3 dots, the cellular morphology, and the increased levels of LC3-II protein. Further study showed that $\beta$-elemene treatment up-regulated Atg5-Atg12 conjugated protein but had little effect on other autophagy-related proteins. PI3K/Akt/ mTOR/p70S6K1 activity was inhibited by $\beta$-elemene. Knockdown of Beclin 1 with small interfering RNA, or cotreatment with the autophagy inhibitor, 3-methyladenine or chlorochine enhanced significantly the antitumor effects of $\beta$-elemene.
\end{abstract}

Conclusions: Our data provides the first evidence that $\beta$-elemene induces protective autophagy and prevents human gastric cancer cells from undergoing apoptosis. A combination of $\beta$-elemene with autophagy inhibitor might thus be a useful therapeutic option for advanced gastric cancer.

\section{Background}

Gastric cancer is one of the top three leading causes of cancer death in China. Most patients present with advanced disease which limits their surgical options. Chemotherapy is thus the major treatment for advanced gastric cancer, but the outcome is still very poor, with a median overall survival time of less than 1 year [1]. Combined chemotherapy with cytotoxic drugs usually leads to severe toxicity which lowers the quality of life of patients. Thus, new agents with high anti-tumor activity but low side effects are urgently needed.

Elemene (1-methyl-1-vinyl-2,4-diisopropenyl-cyclohexane) is a novel lipid-soluble anticancer drug extracted from the traditional Chinese medicinal herb Rhizoma zedoariae [2]. $\beta$-Elemene, the active component of elemene, has been shown to be effective against various tumors such as lung cancer, colorectal cancer and glioblastoma [3-5]. In China, $\beta$-elemene has been used to

\footnotetext{
* Correspondence: qu_xiujuan2001@yahoo.co.jp; cmuliuyunpeng@yahoo.cn Department of Medical Oncology, the First Hospital of China Medical University, Shenyang 110001, P.R.China
}

effectively treat certain types of tumors in the clinic, and it presents fewer side effects than other cytotoxic agents $[6,7]$. However, the mechanisms by which $\beta$-elemene kills cancer cells are still not clear. Recent studies showed that $\beta$-elemene inhibited cell proliferation by inducing apoptosis as well as cell cycle arrest $[3,8]$. Others reported that the apoptosis triggered by $\beta$-elemene was through the mitochondrial-mediated pathway, as it was accompanied by a reduction of Bcl-2, Bcl-X(L) and XIAP $[4,9]$. Yet the exact mechanisms still need to be further elucidated.

Autophagy is an intracellular degradation system that delivers cytoplasmic constituents to the lysosome [10]. Under normal conditions, autophagy is a mechanism for the turnover of proteins and elimination of damaged organelles to maintain cell homeostasis [11]. It starts with the formation of double membrane vesicles (autophagosomes) which engulf organelles or long-lived proteins. The autophagosomes then fuse with lysosomes, forming the autophagolysosome, in which the contents are degraded [10,11]. It has been suggested that autophagy induced under 
pathological conditions functions as an adaptive cell response, allowing the cell to survive bioenergetic stress [12]. However, extensive or persistent autophagy also results in cell death [13]. Thus, autophagy is an important and decisive factor in the balance between cell death and survival.

Recent studies have shown that some chemotherapeutics known to activate apoptosis also induce autophagy [14]. Inhibition of autophagy by pharmacological inhibitors can enhance the anti-tumor activity of cytotoxic agents $[15,16]$. In these cases, autophagy serves as a protector - it prevents cells from undergoing apoptosis. However, autophagy can also do the opposite; it can kill cells by inducing autophagic cell death $[17,18]$. The molecular mechanisms by which autophagy regulates survival and death need to be further studied.

In the present study, we report that $\beta$-elemene induces apoptosis as well as protective autophagy in human gastric cancer cells. Induction of autophagy was associated with inhibition of the PI3K/Akt/mTOR signaling pathway, and inhibition of autophagy could enhance $\beta$-elemene-induced apoptosis.

\section{Methods}

\section{Cell cultures}

The human gastric cancer cells MGC803 and SGC7901 were obtained from the Type Culture Collection of the Chinese Academy of Sciences (Shanghai, China). The cells were cultured in RPMI-1640 medium (Gibco) containing $10 \%$ heat-inactivated fetal bovine serum (FBS), penicillin $(100 \mathrm{U} / \mathrm{mL})$ and streptomycin $(100 \mathrm{mg} / \mathrm{mL})$ at $37^{\circ} \mathrm{C}$ under an atmosphere of $95 \%$ air and $5 \% \mathrm{CO} 2$. The cells were routinely subcultured every 2-3 days, and were all from the logarithmic phase of growth.

\section{Reagents and antibodies}

$\beta$-Elemene was obtained from Yuanda Pharmaceuticals (Dalian, China). 3-Methyladenine (3-MA) and chlorochine (CQ) were purchased from Sigma-Aldrich (St. Louis, Mo. USA). LysoTracker and Hoechst33342 were from Invitrogen (USA). Anti-Bcl-2, anti-Bax, anti-Survivin, anti-actin and anti-Akt antibodies were purchased from Santa Cruz Biotechnology (USA). Anti-LC3, antiBeclin 1, anti-Atg5, anti-Atg9 and anti-Atg16L antibodies were from Novus Biological (Littleton, CO, USA). Anti-caspase 3, anti-poly(ADP-ribose) polymerase (PARP), anti-phospho-Akt (Ser-473), anti-phosphomTOR, anti-mTOR, anti-phospho-p70S6K1, and antip70S6K1 antibodies were purchased from Cell Signaling Technology (USA).

\section{Cell viability assay}

Cell viability was measured using a 3-(4, 5-dimethylthiazol-2-yl)-2, 5-diphenyltetrazolium bromide (MTT) assay.
The cells were seeded at $5 \times 10^{4}$ cells/well in 96-well plates, incubated overnight and then exposed to the indicated concentrations of $\beta$-elemene for the indicated times. Thereafter, $20 \mu \mathrm{l}$ of MTT solution $(5 \mathrm{mg} / \mathrm{mL}$ ) was added to each well, and the cells were incubated for another $4 \mathrm{~h}$ at $37^{\circ} \mathrm{C}$. After removal of the culture medium, the cells were lysed in $200 \mu \mathrm{l}$ of dimethylsulfoxide (DMSO), and the optical density (OD) was measured at $570 \mathrm{~nm}$ with a microplate reader (Model 550; Bio-Rad Laboratories, USA). The following formula was used: cell viability $=(\mathrm{OD}$ of the experimental sample/OD of the control group) $\times 100 \%$.

\section{Analysis of apoptosis}

Cells were seeded at $3 \times 10^{5}$ cells/well in 6-well plates, incubated overnight and then exposed to the indicated concentrations of $\beta$-elemene for the indicated times. Cells were collected and incubated with $1 \mu \mathrm{g} / \mathrm{mL}$ Annexin V for 20 min in the dark. Finally, the samples were evaluated by flow cytometry and the data were analyzed using WinMDI software.

\section{Fluorescence microscopy}

For the analysis of green fluorescent protein-fused LC3 (GFP -LC3) localization, MGC 803 cells were transfected with a plasmid encoding GFP-LC3 (kindly provided by Høyer-Hansen M, Danish Cancer Society) and stably expressing cells were selected with changes of media containing $200 \mu \mathrm{g} / \mathrm{mL}$ of G418. Transfection was performed using Lipofectamine 2000 reagent (Invitrogen, USA), according to the manufacturer's instructions. After treatment of 10 or $50 \mu \mathrm{g} / \mathrm{mL} \beta$-elemene for $24 \mathrm{~h}$, cells were incubated with $50 \mathrm{nmol} / \mathrm{L}$ LysoTracker for $30 \mathrm{~min}$ at room temperature, and the nucleus was stained with Hoechst33342. The images were obtained with a fluorescence microscope (Olympus, Japan). The detection of punctated GFP-LC3 co-locolized with LysoTracker indicated the formation of autophagosomes.

\section{Transmission electron microscopy}

Cells were treated and collected by trypsinization, then fixed with $2.5 \%$ phosphate-buffered gluteraldehyde, postfixed in $1 \%$ phosphate-buffered osmium tetroxide. Cells were then embedded, sectioned, double stained with uranyl acetate and lead citrate, and analyzed using a JEM-1200EX transmission electron microscope (JEOL, Japan).

\section{Western blotting}

Cells were washed twice with ice-cold PBS and solubilized in $1 \%$ Triton lysis buffer [ $1 \%$ Triton $\mathrm{X}-100,50 \mathrm{mmol} / \mathrm{L}$ Tris-Cl (pH 7.4), $150 \mathrm{mmol} / \mathrm{L} \mathrm{NaCl}, 10 \mathrm{mmol} / \mathrm{L}$ EDTA, $100 \mathrm{mmol} / \mathrm{L} \mathrm{NaF}, 1 \mathrm{mmol} / \mathrm{L} \mathrm{Na}_{3} \mathrm{VO}_{4}, 1 \mathrm{mmol} / \mathrm{L}$ PMSF and $2 \mu \mathrm{g} / \mathrm{mL}$ aprotinin] on ice, then quantified using the 
Lowry method. Cell lysate proteins $(50 \mu \mathrm{g})$ were separated by sodium dodecyl sulfate-polyacrylamide gel electrophoresis and electrophoretically transferred to nitrocellulose membranes (Immoblin-P; Millipore, USA). The membranes were blocked with $5 \%$ skim milk in TBST buffer [10 mmol/L Tris (pH 7.4), $150 \mathrm{mmol} / \mathrm{L} \mathrm{NaCl}$ and $0.1 \%$ Tween-20] at room temperature for $1 \mathrm{~h}$ and incubated overnight at $4^{\circ} \mathrm{C}$ with the indicated primary antibodies. After the membranes were washed with TBST buffer, they were reacted with the appropriate horseradish peroxidaseconjugated secondary antibodies for $30 \mathrm{~min}$ at room temperature. After extensive washing with TBST buffer, the proteins were visualized with enhanced chemiluminescence reagent (SuperSignal Western Pico Chemiluminescent Substrate; Pierce, Rockford, IL, USA). The images were analyzed using NIH Image J software.

\section{Clonogenic assay}

Cells were seeded at $5 \times 10^{4}$ cells/well in 12-well plates and treated with either $50 \mu \mathrm{g} / \mathrm{mL} \beta$-elemene or $20 \mu \mathrm{mol} / \mathrm{L} \mathrm{CQ}$, or co-treatment with $\beta$-elemene and CQ for $6 \mathrm{~h}$. Cells were then plated (in triplicate) at 200 cells per well into 12 -well plates with fresh drug-free medium. Cells were incubated for an additional 14 days, and the clones in each well were stained, counted and photographed.

\section{RNA interference}

Small interfering RNA corresponding to the human Beclin 1 cDNA sequence (5'-CAGTTTGGCACAATCAATAtt3') [19] and a control siRNA (5'-UUCUCCGAACGUGUCACGUtt-3') were from Genechem Co. (Shanghai, China). Cells were transfected with either Beclin 1 siRNA or control siRNA at $100 \mathrm{nmol} / \mathrm{L}$ using DharmaFECT transfection agent (Dharmacon Research, CO, USA) according to the manufacturer's guidelines. Forty-eight hours after transfection, the cells were subcultured for further use. The expression of Beclin 1 was verified by western blotting.

\section{Statistical analysis}

The experiments were repeated at least three times. Data are expressed as the means \pm SD. Differences in the results for two groups were evaluated by the Student's t-test. $\mathrm{P}<0.05$ was considered to be statistically significant.

\section{Results}

$\beta$-Elemene inhibited cell viability and induced apoptosis Human gastric cancer MGC803 cells were treated with $\beta$-elemene at concentrations ranging from $10 \mu \mathrm{g} / \mathrm{mL}$ to $200 \mu \mathrm{g} / \mathrm{mL}$ for 24,48 or $72 \mathrm{~h}$. Cell viability assays showed that $\beta$-elemene inhibited cell growth in a dose-dependent manner (Figure $1 \mathrm{~A}$ ). The $\mathrm{IC}_{50}$ values of $\beta$-elemene at 24, 48 and $72 \mathrm{~h}$ were $80.03 \mu \mathrm{g} / \mathrm{mL}, 56.03 \mu \mathrm{g} / \mathrm{mL}$ and
$45.05 \mu \mathrm{g} / \mathrm{mL}$, respectively. Flow cytometry assays showed a significant increase in the apoptotic population among the cells treated with $\beta$-elemene at $24 \mathrm{~h}$ (Figure $1 \mathrm{~B}$ ). To further confirm that apoptosis was induced by $\beta$-elemene, western blotting was performed to detect the cleavage of caspase 3 as well as PARP. As shown in Figure $1 \mathrm{C} \beta$-elemene clearly cleaved pro-caspase 3 and PARP to their active forms. The effects of $\beta$-elemene on the expression of apoptosis associated proteins were further investigated. Western blotting showed that $\beta$-elemene had little effect on the expression of Bax or Bcl-2, but significantly down-regulated the level of Survivin (Figure 1D and $1 \mathrm{E})$. These data indicated that $\beta$-elemene inhibits cell viability through inducing apoptosis in human gastric cancer cells.

\section{$\beta$-Elemene induced autophagosome formation}

It has been reported that some lipid-soluble anti-tumor agents such as oleandrin could simultaneously induce apoptosis and autophagy [20], so we asked if there was any autophagy in the cells treated with $\beta$-elemene. MGC803 cells stably expressing GFP-LC3 were treated with 10 or $50 \mu \mathrm{g} / \mathrm{mL} \beta$-elemene for $24 \mathrm{~h}$, and the localization of GFP-LC3 was evaluated under fluorescent microscopy. As shown in Figure 2A, only a few LC3-positive puncta were observed in untreated control cells. However, in the cells treated with $10 \mu \mathrm{g} / \mathrm{mL} \beta$-elemene, over $30 \%$ of cells were observed with LC3-positive puncta, and in the cells treated with $50 \mu \mathrm{g} / \mathrm{mL} \beta$-elemene, more than $90 \%$ of cells showed LC3-positive puncta. GFP-LC3 co-localized with LysoTracker after treatment with $\beta$-elemene, which suggests the accumulation of autophagosomes. The formation of autophagosomes was further confirmed by transmission electron microscopy. Upon treatment of $50 \mu \mathrm{g} / \mathrm{mL} \beta$ elemene many autophagic vesicles, double membrane enclosed vesicle containing engulfed organelles, were observed in the cytoplasm (Figure 2B). Meanwhile, $\beta$ elemene treatment also significantly increased LC3-II levels as demonstrated by western blotting (Figure $2 \mathrm{C}$ ). These data indicate that $\beta$-elemene treatment not only results in apoptosis, but also induces autophagy.

\section{Effects of $\beta$-elemene on autophagy-associated proteins}

Autophagy is regulated by a group of proteins called Atg (autophagy-related) proteins [10]. Some stimuli can modulate autophagy simply by changing the expression of certain Atg protein [21]. To determine if $\beta$-elemene could affect the expression of Atg proteins, MGC803 cells were treated with $50 \mu \mathrm{g} / \mathrm{mL} \beta$-elemene for $24 \mathrm{~h}$ and the levels of some Atg proteins were detected by western blotting. After treatment with $\beta$-elemene, the level of Atg5-Atg12 conjugated protein was up-regulated, whereas the expression of Beclin1, Atg5, Atg9 and Atg16L was not affected significantly (Figure 3A and 3B). 


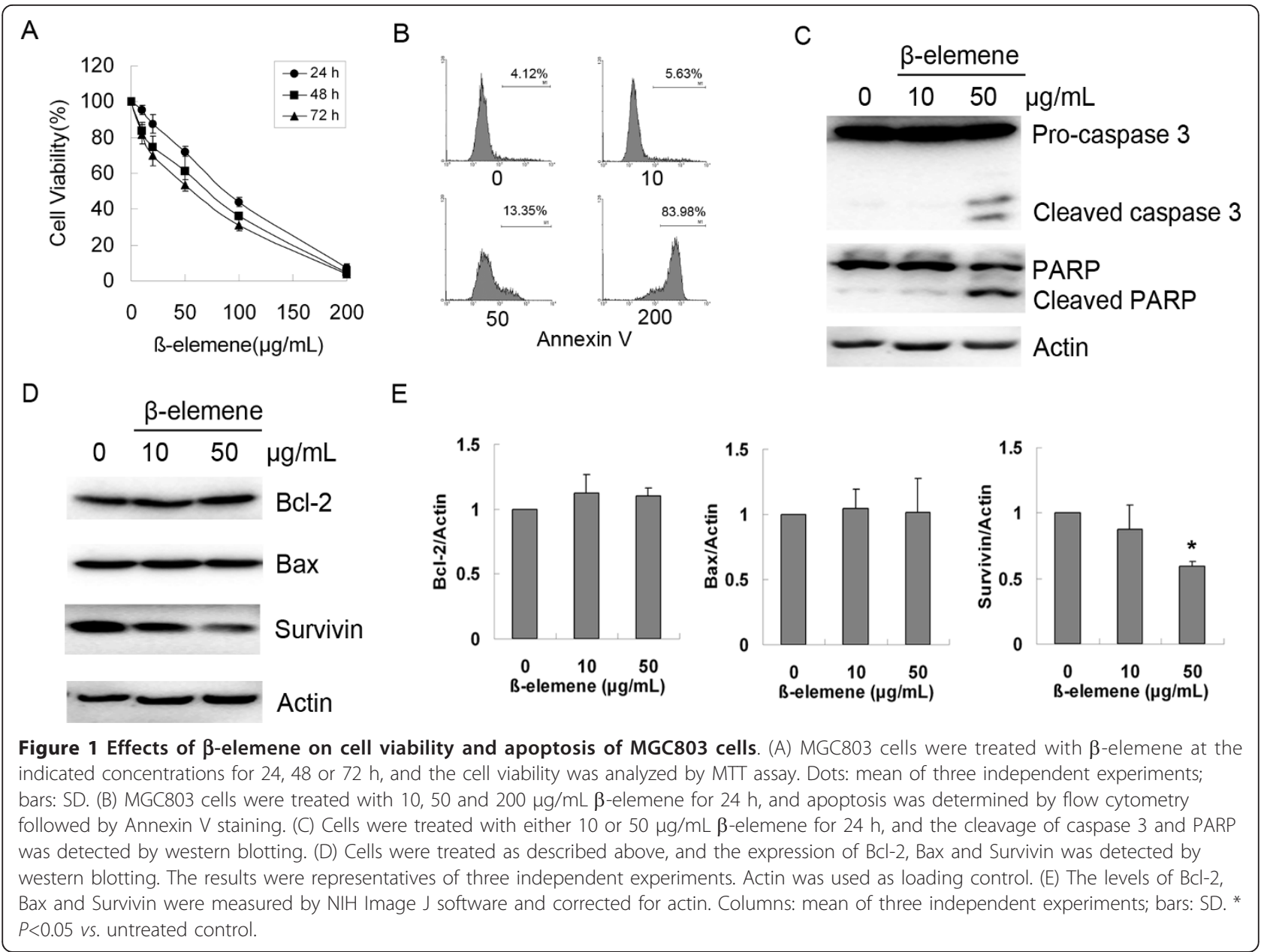

These data suggest that the up-regulation of Atg5-Atg12 conjugated protein might contribute to the induction of autophagy by $\beta$-elemene.

\section{$\beta$-elemene inhibited PI3K/Akt/mTOR signalling pathway}

It has been well documented that the PI3K/Akt/mTOR/ p70S6K1 signalling pathway plays a key role in regulating both apoptosis and autophagy, so the effects of $\beta$ elemene on the activity of this pathway were studied next. Cells were treated with 10 or $50 \mu \mathrm{g} / \mathrm{mL} \beta$-elemene for $24 \mathrm{~h}$, and the levels of phospho-Akt, phosphomTOR and phospho-p70S6K1 were detected by western blotting. After treatment with $50 \mu \mathrm{g} / \mathrm{mL} \beta$-elemene, the level of phospho-Akt was obviously down-regulated, leading to the down-regulation of downstream phosphomTOR as well as phospho-p70S6K1 (Figure 4A). A low dose $(10 \mu \mathrm{g} / \mathrm{mL})$ of $\beta$-elemene had little effect on PI3K/ $\mathrm{Akt} / \mathrm{mTOR} / \mathrm{p} 70 \mathrm{~S} 6 \mathrm{~K} 1$ activity. Interestingly, a transient activation of PI3K/Akt/mTOR/p70S6K1 was observed after the cells were exposed to $\beta$-elemene for short times. As shown in Figure 4B, the level of phospho-Akt increased after $4 \mathrm{~h}$, stayed active until $8 \mathrm{~h}$, and went down after $16 \mathrm{~h}$. Similar changes were observed on the phosphorylation of mTOR and p70S6K1. The cleavage of PARP and conversion of LC3 I to LC3 II was also seen following treatment with $50 \mu \mathrm{g} / \mathrm{mL} \beta$-elemene at $16 \mathrm{~h}$ and $24 \mathrm{~h}$, consistent with the change of PI3K/Akt/ mTOR/p70S6K1 activity (Figure 4C). These data indicated that $\beta$-elemene induced apoptosis and autophagy might be due to its inhibition of the PI3K/Akt/mTOR/ p70S6K1 signalling pathway.

\section{$\beta$-Elemene-induced autophagy protected MGC803 cells from undergoing apoptosis}

Since autophagy can result in both survival and cell death, we then asked whether $\beta$-elemene-induced autophagy is protective or pro-apoptotic. MGC803 cells were treated with either $50 \mu \mathrm{g} / \mathrm{mL} \beta$-elemene or $20 \mu \mathrm{mol} / \mathrm{L}$ CQ (an inhibitor of autophagy which blocks the fusion of autophagosomes with lysosomes, stopping autophagy at the late phase), or co-treated with $\beta$ elemene and CQ for $24 \mathrm{~h}$. Cell viability assays showed that co-treatment with $\beta$-elemene and CQ significantly decreased cell viability, compared with the cells treated 


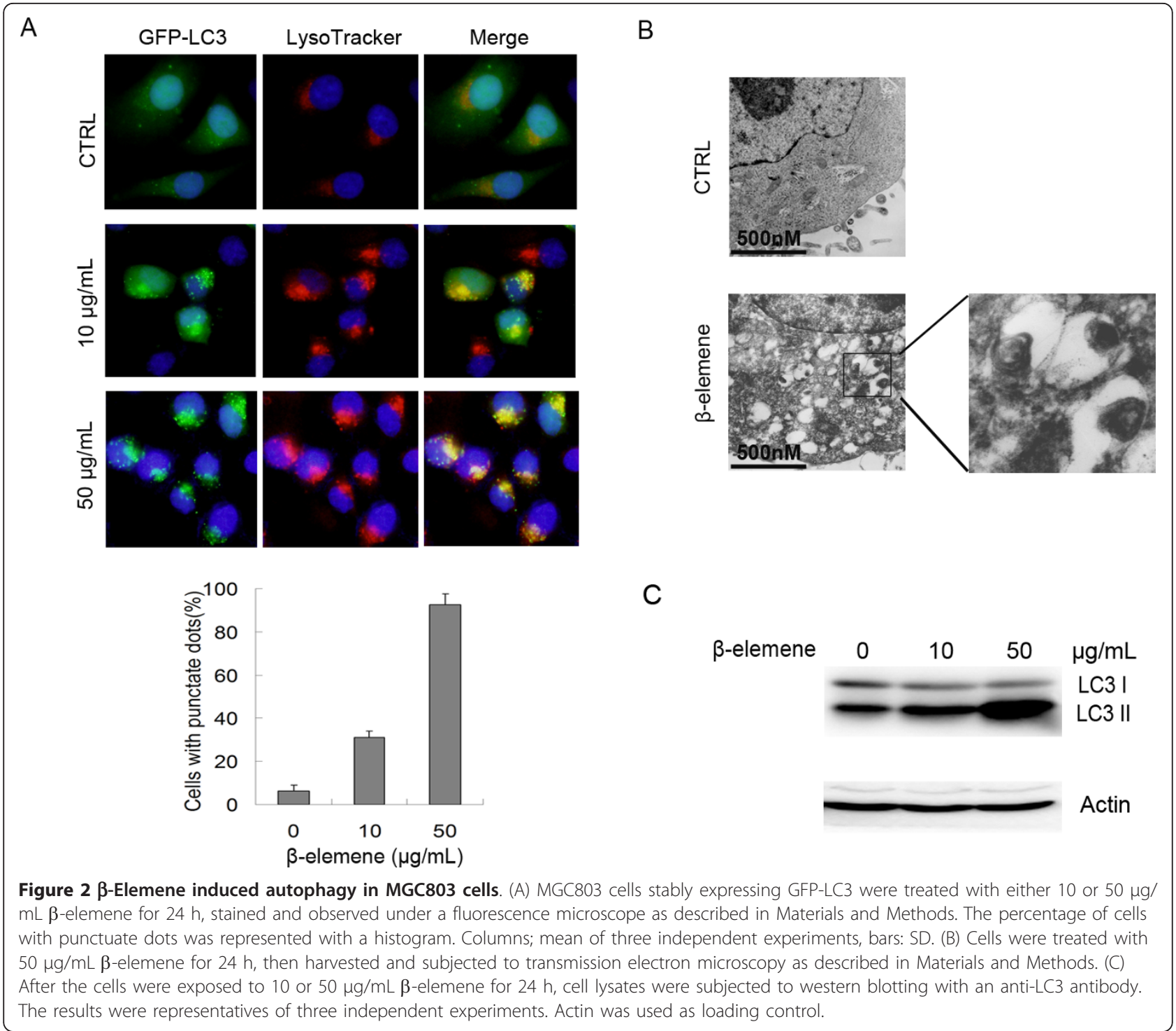

with $\beta$-elemene alone $(48.50 \pm 5.07 \%$ vs. $78.27 \pm 1.57 \%$, $P<0.05$ ) (Figure $5 \mathrm{~A}$ ). Co-treatment with $\beta$-elemene and $\mathrm{CQ}$ also significantly reduced the clone formation ability of the cells and increased the apoptotic population compared with the cells treated with $\beta$-elemene alone (Figure $5 \mathrm{~B}$ and $5 \mathrm{C}$ ). To confirm the effect of autophagy inhibition by the pharmacologic agent CQ on $\beta$-elemene-induced apoptosis, an RNA interference approach was used to knock down the expression of Beclin 1. Figure 5D shows that the level of Beclin 1 was significantly decreased in Beclin 1 siRNA-treated cells. Compared with the results in siRNA controls, knockdown of Beclin 1 decreased significantly the cell viability, and enhanced $\beta$-elemene-induced apoptosis (Figure $5 \mathrm{E}$ and $5 \mathrm{~F}$ ). These data indicate that blockage of autophagy enhanced the antitumor effect of $\beta$ elemene in MGC803 cells.

\section{$\beta$-Elemene induced protective autophagy in SGC7901 gastric cancer cells}

To prove that the apoptosis and autophagy induced by $\beta$-elemene is not cell-specific, we examined the antitumor effect of $\beta$-elemene on another human gastric cancer cell line, SGC7901. We found that $\beta$-elemene inhibited the viability of SGC7901 cells in a dose-dependent manner, and the $\mathrm{IC}_{50}$ values at 24,48 and $72 \mathrm{~h}$ were $89.68 \mu \mathrm{g} / \mathrm{mL}, 75.88 \mu \mathrm{g} / \mathrm{mL}$ and $67.13 \mu \mathrm{g} / \mathrm{mL}$, respectively (Figure 6A). $\beta$-Elemene inhibited mTOR activity and induced apoptosis and autophagy, which were evidenced by the cleavage of PARP and the conversion of LC3-I to LC3-II (Figure 6B). The contribution of autophagy to $\beta$-elemene-induced apoptosis in SGC7901 cells was evaluated further by co-treating the cells with $\beta$-elemene and the autophagy inhibitor, 3-MA or CQ. Compared with the cells treated with $\beta$-elemene 

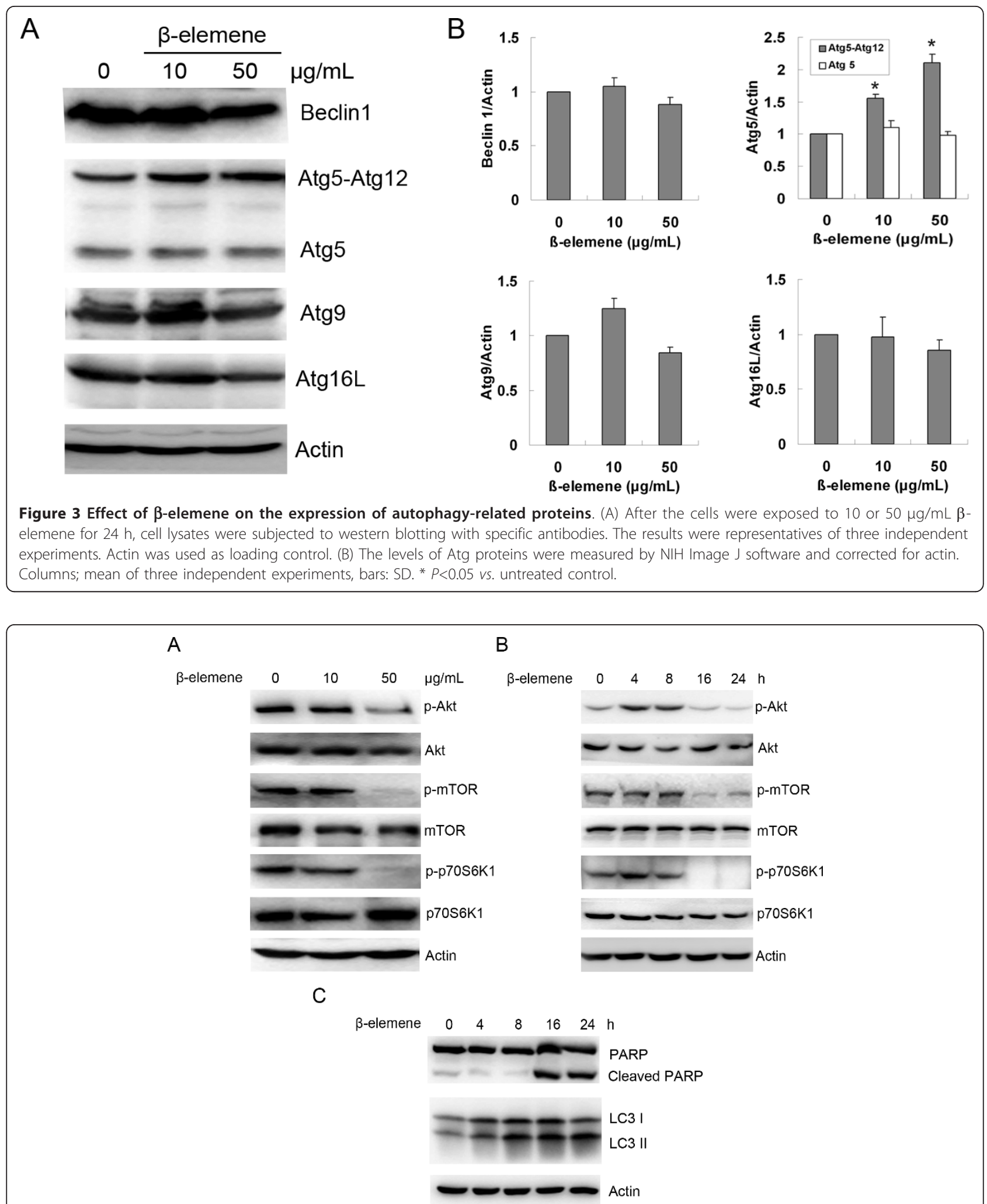

Figure 4 Effect of $\beta$-elemene on the PI3K/Akt/mTOR/p70S6K1 signalling pathway. (A) MGC803 cells were exposed to $10 \mathrm{or} 50 \mu \mathrm{g} / \mathrm{mL} \beta$ elemene for $24 \mathrm{~h}$, and the expression of phospho-Akt, phospho-mTOR and phospho-p70S6K1 was detected by western blotting. (B) and (C) Cells were treated with $50 \mu \mathrm{g} / \mathrm{mL} \beta$-elemene for the indicated times, and cell lysates were subjected to western blotting with specific antibodies. The results were representatives of three independent experiments. Actin was used as loading control. 


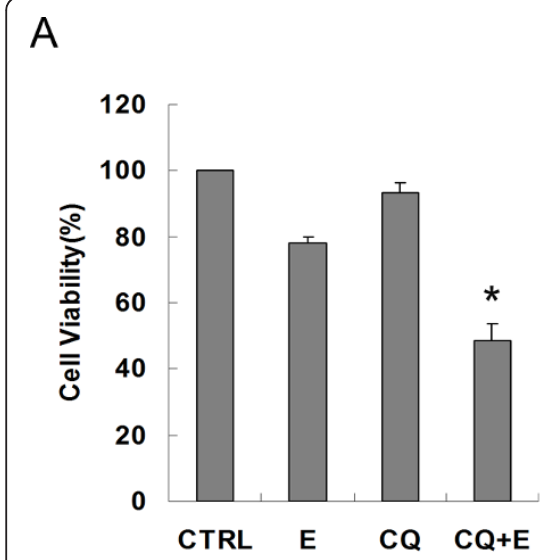

$\mathrm{B}$

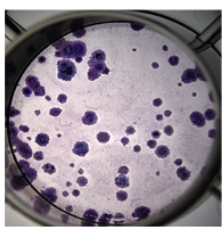

CTRL
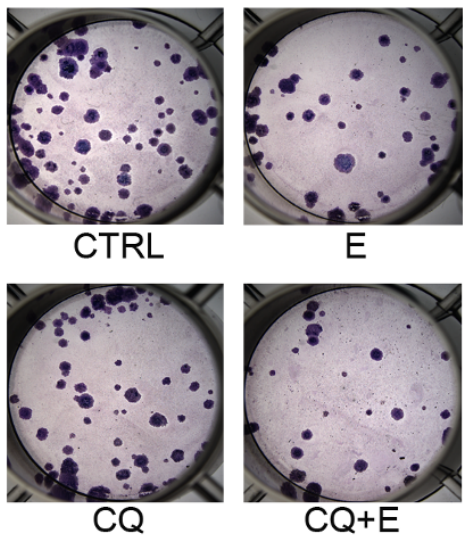

$\mathrm{E}$

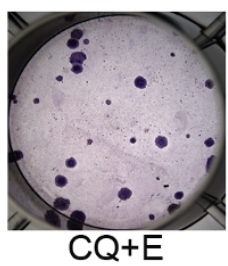

$\mathrm{F}$

D
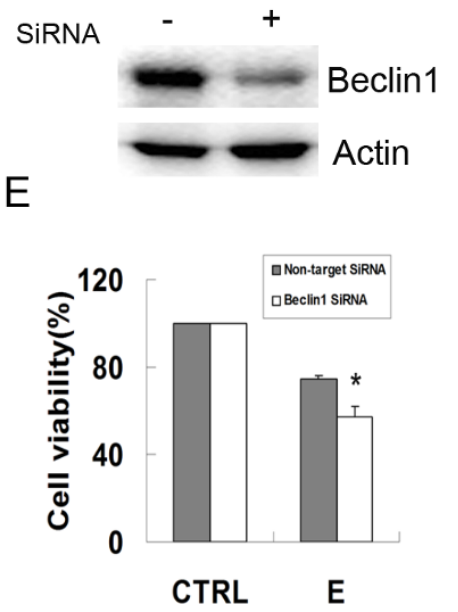

CTRL


Annexin V

\section{Annexin $\mathrm{V}$}

Figure 5 Inhibition of autophagy enhanced the anti-tumor effect of $\boldsymbol{\beta}$-elemene on MGC803 cells. (A) MGC803 cells were exposed to either $50 \mu \mathrm{g} / \mathrm{mL} \beta$-elemene or $20 \mu \mathrm{mol} / \mathrm{L} C Q$, or a combined treatment of $\beta$-elemene and CQ for $24 \mathrm{~h}$, and cell viability was measured by MTT assay. (B) Cells were treated with $50 \mu \mathrm{g} / \mathrm{mL} \beta$-elemene or $20 \mu \mathrm{mol} / \mathrm{L} C Q$, or a combined treatment of $\beta$-elemene and CQ for $6 \mathrm{~h}$, and the clone formation ability was analyzed. Columns: mean of three independent experiments; bars: SD. ${ }^{*} P<0.05$ vs. cells treated with $\beta$-elemene alone. (C) Cells were treated as described in $\mathrm{A}$ and apoptosis was analyzed by flow cytometry following Annexin $V$ staning. (D) Cells were transfected with either Beclin1 siRNA or a non-target control siRNA for $48 \mathrm{~h}$, and the expression of Beclin 1 was verified by western blotting. (E) and (F) Fortyeight hours after transfection, the cells were treated with $50 \mu \mathrm{g} / \mathrm{mL} \beta$-elemene for another $24 \mathrm{~h}$, and cell viability (E) and apoptosis (F) were analyzed. ${ }^{*} P<0.05$ vs. cells transfected with control siRNA.

alone, co-treatment with $\beta$-elemene and 3-MA or CQ reduced significantly the viability and clone formation ability of the cells, and increased the apoptotic population (Figure 6C, D and 6E). Similar results from these two human gastric cancer lines indicate that autophagy induced by $\beta$-elemene served in a protective manner, and blockage of autophagy enhanced the anti-tumor effect of $\beta$-elemene in human gastric cancer cells.

\section{Discussion}

Recently, some traditional Chinese medicines have exhibited promising anti-tumor activity. $\beta$-Elemene as a novel anti-cancer herbal medicine has shown broad anti-tumor effects in vitro and in vivo [2-5]. It has been approved by the State Food and Drug Administration of China for the treatment of malignant effusion and some solid tumors. However, the effects of $\beta$-elemene on gastric cancer cells have not been documented. In the present study, we provide the first evidence that $\beta$-elemene could inhibit the proliferation of human gastric cancer cells.

Previous study showed that $\beta$-elemene induced both G2/M phase arrest and apoptotic cell death in nonsmall cell lung cancer cells [3]; whereas in ovarian carcinoma cells it only induced cell cycle arrest at G2/M phase [8]. In the present study $\beta$-elemene induced obvious apoptosis in gastric cancer cells, but had little effect on cell cycle distribution. This may be due to the 


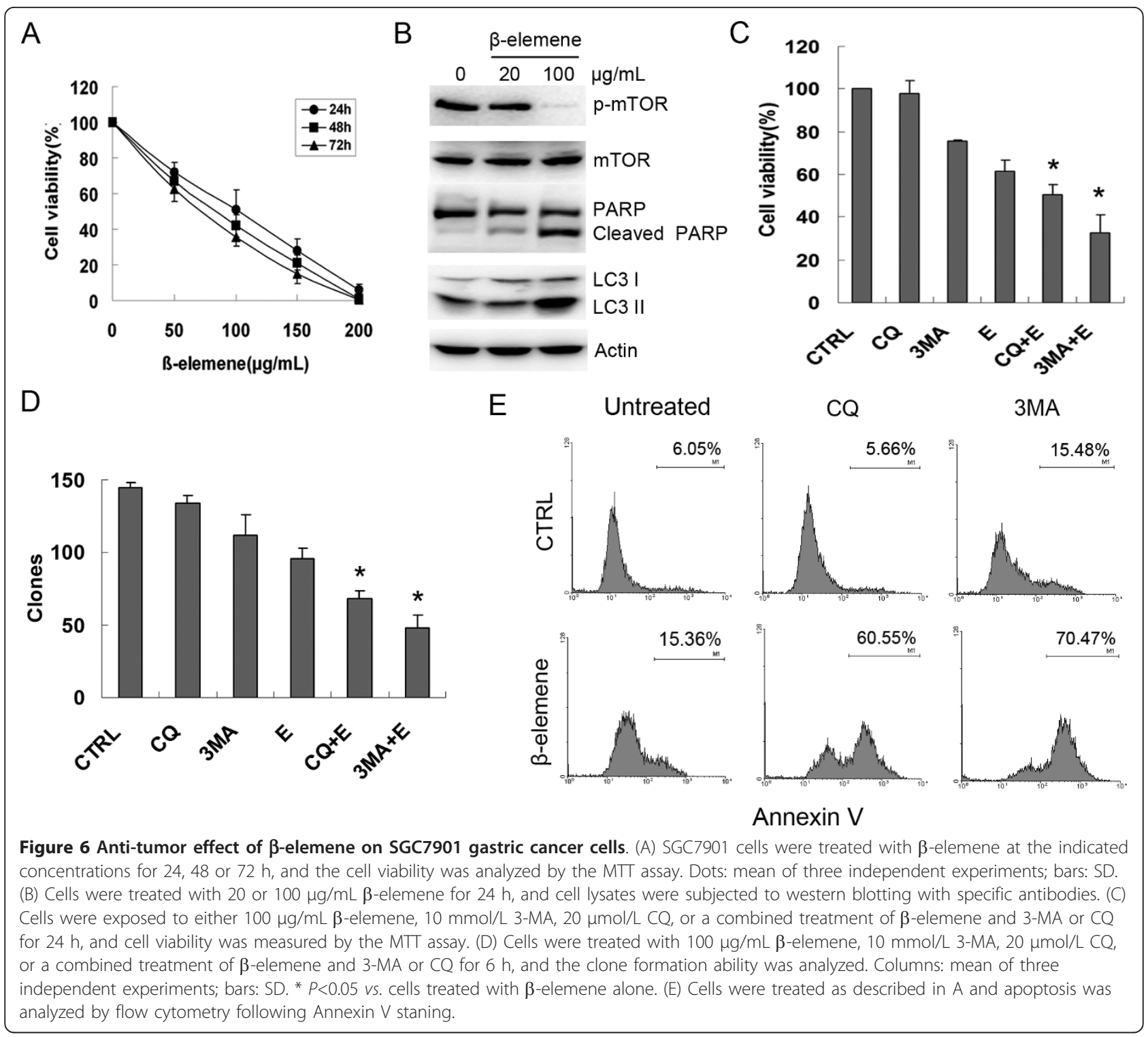

different regulating mechanism of cell cycle progress in different types of tumor cells.

Meanwhile, in our study a robust autophagy was observed among the cells treated with $\beta$-elemene, which was shown by the increase of punctate LC3 and the morphologic changes. Western blotting also showed a conversion of LC3-I to LC3-II. These specific changes of LC3 have been characterized as an autophagosomal marker in mammalian autophagy. This is the first demonstration that $\beta$-elemene could induce autophagy. It has been demonstrated that autophagy is activated by some anti-tumor drugs while they induce apoptosis [14-16]. The autophagy induced by these agents leads to either survival or autophagic cell death. Whether $\beta$-elemene-induced autophagy is a protective or a deadly response was confirmed later.
Although the detailed mechanisms regulating autophagy have not been well documented, just like for apoptosis, the process of autophagy is controlled under a group of evolutionarily conserved proteins, the Atg proteins [10]. Accumulated evidence suggest that the induction of autophagy is associated with the up-regulation of certain Atg proteins [21-23]. Thyagarajan et al. reported that triterpenes-induced autophagy is accompanied by the up-regulation of Beclin 1 [21]. Others reported that increased transcription of Atg5 can lead to autophagy [23]. In the present study $\beta$-elemene induced autophagy without alternating significantly the levels of Beclin 1, Atg5, Atg9 or Atg16L, while the expression of the Atg5Atg12 conjugated protein was up-regulated significantly. This is similar to the results reported by Kim et al that irradiation up-regulated Atg5-Atg12 and activated 
autophagy [24]. Along with the conversion of LC3, the changes of these molecular markers finally lead to autophagy.

The PI3K/Akt pathway has been reported to play an important role in the inhibition of apoptosis [25-28]. Once activated, Akt phosphorylates downstream mTOR, leading to the phospharylation of its target p70S6K1, which promotes cell growth and inhibits apoptosis [29]. Moreover, recent studies have suggested that Survivin is positively regulated by the PI3K/Akt/p70S6K1 pathway [30]. In our study $\beta$-elemene inhibited the phospharylation of Akt, mTOR, and p70S6K1, and down-regulated the expression of Survivin but not other apoptotic proteins. This indicated that inhibition of PI3K/Akt/mTOR/ p70S6K1 and Survivin by $\beta$-elemene might lead to the induction of apoptosis. Meanwhile, mTOR is also a key regulator of autophagy, and inhibition of mTOR activity by some agents has been reported to activate autophagy [31-33]. This may explain the phenomenon of autophagy among the cells treated with $\beta$-elemene in the present study.

Since autophagy can result in both survival and cell death, we then investigated whether the autophagy induced by $\beta$-elemene was a protective response or a process leading to death. We found that inhibition of autophagy by the autophagy inhibitor, or by genetic knockdown of Beclin 1, the Atg protein essential for autophagy initiation, enhanced significantly the antitumor effect of $\beta$-elemene. This phenomenon was also seen in another gastric cancer cell line, SGC7901. These data suggest that the inhibition of PI3K/Akt/mTOR activity by $\beta$-elemene resulted in two opposite consequences: on the one hand, it inhibited cell viability and induced apoptosis, which led to death; on the other hand, it activated a protective autophagy to adapt to the stressful conditions and protect cells from death. Inhibition of protective autophagy might be a good way to enhance the anti-tumor effect of $\beta$-elemene.

\section{Conclusions}

Taken together, our study provides the first evidence that $\beta$-elemene can inhibit the proliferation of human gastric cancer cells by inducing apoptosis. The anti-cancer effect of $\beta$-elemene was associated with inhibition of the PI3K/Akt/mTOR/p70S6K1 signaling pathway, which also led to the activation of a protective autophagy. Inhibition of autophagy significantly enhanced the apoptosis-inducing ability, which suggests that the combination of $\beta$-elemene with an autophagy inhibitor might be useful for the treatment of advanced gastric cancer.

\section{Acknowledgements}

We thank Dr. Høyer-Hansen M (Danish Cancer Society, Denmark) for providing the GFP-LC3 plasmid.
Financial support: YL (Chinese National Foundation of National Sciences grants 30770993); XQ (China Postdoctor Foundation of Science grants 20070411081); JL (Fund for Scientific Research of The First Hospital of China Medical University, fsfh 1002); YZ (The Doctor Startup Fund Program Funded by CSCO-King Kong Elemene).

\section{Authors' contributions}

$J$ carried out the cellular and biochemistry study, participated in the transfection and drafted the manuscript. $Y Z$ and LX carried out the transfection and participated in fluorescence microscopy assays. JQ and $\mathrm{KH}$ carried out the transmission electron microscopy assays. JZ participated in the biochemistry study. XQ and YL conceived of the study, and participated in its design and coordination and helped to draft the manuscript. All authors read and approved the final manuscript.

\section{Competing interests}

The authors declare that they have no competing interests.

Received: 6 October 2010 Accepted: 20 May 2011

Published: 20 May 2011

\section{References}

1. Shah MA, Kelsen DP: Gastric cancer: a primer on the epidemiology and biology of the disease and an overview of the medical management of advanced disease. J Natl Compr Canc Netw 2010, 8:437-447.

2. Li QQ, Wang G, Zhang M, Cuff CF, Huang L, Reed E: beta-Elemene, a novel plant-derived antineoplastic agent, increases cisplatin chemosensitivity of lung tumor cells by triggering apoptosis. Oncol Rep 2009, 22:161-170.

3. Wang G, Li X, Huang F, Zhao J, Ding H, Cunningham C, Coad JE, Flynn DC, Reed E, Li QQ: Antitumor effect of beta-elemene in non-small-cell lung cancer cells is mediated via induction of cell cycle arrest and apoptotic cell death. Cell Mol Life Sci 2005, 62:881-893.

4. Xie CY, Yang W, Li M, Ying J, Tao SJ, Li K, Dong JH, Wang XS: Cell apoptosis induced by delta-elemene in colorectal adenocarcinoma cells via a mitochondrial-mediated pathway. Yakugaku Zasshi 2009, 129:1403-1413.

5. Yao $Y Q$, Ding $X$, Jia $Y C$, Huang $C X$, Wang $Y Z, X u$ YH: Anti-tumor effect of beta-elemene in glioblastoma cells depends on p38 MAPK activation. Cancer Lett 2008, 264:127-134.

6. Wang J, Zhang H, Sun Y: Phase III clinical trial of elemenum emulsion in the management of malignant pleural and peritoneal effusions. Zhonghua Zhong Liu Za Zhi 1996, 18:464-447.

7. Tan P, Zhong W, Cai W: Clinical study on treatment of 40 cases of malignant brain tumor by elemene emulsion injection. Zhongguo Zhong Xi Yi Jie He Za Zhi 2000, 20:645-648.

8. Li X, Wang G, Zhao J, Ding H, Cunningham C, Chen F, Flynn DC, Reed E, Li QQ: Antiproliferative effect of beta-elemene in chemoresistant ovarian carcinoma cells is mediated through arrest of the cell cycle at the G2-M phase. Cell Mol Life Sci 2005, 62:894-904.

9. Li QQ, Wang G, Reed E, Huang L, Cuff CF: Evaluation of Cisplatin in Combination with beta-Elemene as a Regimen for Prostate Cancer Chemotherapy. Basic Clin Pharmacol Toxicol 2010.

10. Mizushima N: Autophagy: process and function. Genes Dev 2007, 21:2861-2873.

11. Mizushima N: The pleiotropic role of autophagy: From protein metabolism to bactericide. Cell Death Differ 2005, 12:1535-1541.

12. Levine B: Cell biology: autophagy and cancer. Nature 2007, 446:745-747.

13. Levine B, Yuan J: Autophagy in cell death: an innocent convict? J Clin Invest 2005, 115:2679-2688.

14. Li X, Fan Z: The epidermal growth factor receptor antibody cetuximab induces autophagy in cancer cells by downregulating HIF-1 \{alpha\} and $\mathrm{Bcl}-2$ and activating the beclin 1/hVps34 complex. Cancer Res 2010, 70:5942-5952.

15. Sasaki $K$, Tsuno NH, Sunami $E$, Tsurita G, Kawai K, Okaji $Y$, Nishikawa $T$, Shuno Y, Hongo K, Hiyoshi M, Kaneko M, Kitayama J, Takahashi K, Nagawa $\mathrm{H}$ : Chloroquine potentiates the anti-cancer effect of 5fluorouracil on colon cancer cells. BMC Cancer 2010, 10:370.

16. Amaravadi RK, Yu D, Lum JJ, Bui T, Christophorou MA, Evan Gl, ThomasTikhonenko A, Thompson CB: Autophagy inhibition enhances therapyinduced apoptosis in a Myc-induced model of lymphoma. J Clin Invest 2007, 117:326-336. 
17. Hwang MS, Baek WK: Glucosamine induces autophagic cell death through the stimulation of ER stress in human glioma cancer cells. Biochem Biophys Res Commun 2010, 399:111-6.

18. Le XF, Mao W, Lu Z, Carter BZ, Bast RC Jr: Dasatinib induces autophagic cell death in human ovarian cancer. Cancer 2010, 116:4980-4990.

19. Park KJ, Lee SH, Kim TI, Lee HW, Lee CH, Kim EH, Jang JY, Choi KS, Kwon MH, Kim YS: A human scFv antibody against TRAIL receptor 2 induces autophagic cell death in both TRAlL-sensitive and TRAILresistant cancer cells. Cancer Res 2007, 67: 7327-7334.

20. Newman RA, Kondo Y, Yokoyama T, Dixon S, Cartwright C, Chan D, Johansen M, Yang P: Autophagic cell death of human pancreatic tumor cells mediated by oleandrin, a lipid-soluble cardiac glycoside. Integr Cancer Ther 2007, 6:354-364.

21. Thyagarajan A, Jedinak A, Nguyen H, Terry C, Baldridge LA, Jiang J, Sliva D: Triterpenes from Ganoderma Lucidum induce autophagy in colon cancer through the inhibition of p38 mitogen-activated kinase (p38 MAPK). Nutr Cancer 2010, 62:630-640.

22. Erlich S, Shohami E, Pinkas-Kramarski R: Neurodegeneration induces upregulation of Beclin 1. Autophagy 2006, 2:49-51.

23. Zhu K, Dunner K Jr, McConkey DJ: Proteasome inhibitors activate autophagy as a cytoprotective response in human prostate cancer cells. Oncogene 2010, 29:451-462.

24. Kim KW, Mutter RW, Cao C, Albert JM, Freeman M, Hallahan DE, Lu B: Autophagy for cancer therapy through inhibition of pro-apoptotic proteins and mammalian target of rapamycin signaling. I Biol Chem 2006, 281:36883-36890

25. Kennedy SG, Wagner AJ, Conzen SD, Jordán J, Bellacosa A, Tsichlis PN Hay N: The PI 3-kinase/Akt signaling pathway delivers an anti-apoptotic signal. Genes Dev 1997, 11:701-713.

26. Qu X, Zhang Y, Li Y, Hu X, Xu Y, Xu L, Hou K, Sada K, Liu Y: Ubiquitin ligase $\mathrm{Cbl}-\mathrm{b}$ sensitizes leukemia and gastric cancer cells to anthracyclines by activating the mitochondrial pathway and modulating Akt and ERK survival signals. FEBS Lett 2009, 583:2255-2262.

27. Qu JL, Qu XJ, Zhao MF, Teng YE, Zhang Y, Hou KZ, Jiang YH, Yang XH, Liu YP: Gastric cancer exosomes promote tumour cell proliferation through PI3K/Akt and MAPK/ERK activation. Dig Liver Dis 2009, 41:875-880.

28. Qu X, Li Y, Liu J, Xu L, Zhang Y, Hu X, Hou K, Liu Y: Cbl-b promotes chemotherapy-induced apoptosis in rat basophilic leukemia cells by suppressing PI3K/Akt activation and enhancing MEK/ERK activation. Mol Cell Biochem 2010, 340:107-114.

29. Franke TF, Hornik CP, Segev L, Shostak GA, Sugimoto C: PI3K/Akt and apoptosis: size matters. Oncogene 2003, 22:8983-8998.

30. Zhao P, Meng Q, Liu LZ, You YP, Liu N, Jiang BH: Regulation of survivin by PI3K/Akt/p70S6K1 pathway. Biochem Biophys Res Commun 2010, 395:219-224.

31. Jung CH, Ro SH, Cao J, Otto NM, Kim DH: mTOR regulation of autophagy. FEBS Lett 2010, 584:1287-1295.

32. Nakatsu $Y$, Kotake $Y$, Takai $N$, Ohta S: Involvement of autophagy via mammalian target of rapamycin (mTOR) inhibition in tributyltin-induced neuronal cell death. J Toxicol Sci 2010, 35:245-251.

33. Fu L, Kim YA, Wang X, Wu X, Yue P, Lonial S, Khuri FR, Sun SY: Perifosine inhibits mammalian target of rapamycin signaling through facilitating degradation of major components in the mTOR axis and induces autophagy. Cancer Res 2009, 69:8967-8976.

\section{Pre-publication history}

The pre-publication history for this paper can be accessed here: http://www.biomedcentral.com/1471-2407/11/183/prepub

\section{doi:10.1186/1471-2407-11-183}

Cite this article as: Liu et al:: $\beta$-Elemene-induced autophagy protects human gastric cancer cells from undergoing apoptosis. BMC Cancer 2011 11:183.

\section{Submit your next manuscript to BioMed Central and take full advantage of:}

- Convenient online submission

- Thorough peer review

- No space constraints or color figure charges

- Immediate publication on acceptance

- Inclusion in PubMed, CAS, Scopus and Google Scholar

- Research which is freely available for redistribution

Submit your manuscript at www.biomedcentral.com/submit 